\title{
Identification of work-related exposure to carcinogenic substances in Germany
}

\author{
S. Gabriel, M. Steinhausen \& R. Van Gelder \\ Institute for Occupational Safety and Health, Sankt Augustin, Germany
}

\begin{abstract}
Occupational exposures to carcinogenic substances like benzo[a]pyrene, ethylenoxide, trichlorethene or butadiene occur in variety fields of industry. The risk strategy for carcinogenic substances in Germany entails a system for assessing hazards due to exposure at the workplace.

Substance-specific concentration values were determined to which a certain risk of contracting work-related cancer as a result of exposure on a day-to-day basis at work is assigned. Below an acceptance concentration, exposure is deemed acceptable; above a tolerance concentration, it is no longer deemed tolerable. Ranges of low, medium and high risk can thus be distinguished and subsequently linked to measures for minimization of the exposure which are not specific to a particular substance.

The data is recorded in the measurement system for exposure asssessment MGU and is documented in the MEGA exposure database. By comparing the sub-stance-specific acceptance or tolerance concentrations with data from MEGA it is possible to identify workplaces at which employees are exposed to a higher than the accepted risk of contracting occupationally induced cancer.

Evaluations show that over $50 \%$ of the values measured in each case for ethylene oxide and trichlorethene are above the respective acceptance concentration. In many cases, the tolerance concentration is exceeded by the 75 th or even the 50th percentiles of sectoral groups or groups of working areas. For example, for benzo[a]pyrene, 662 measured values lie above the analytical limit of detection, 246 of these in the medium-risk range, 414 in the high-risk range. Only 132 measured values can be clearly assigned to low-risk exposure. In contrast, for 1,3-butadiene all measured values with just one exception lie below the analytical limit of detection.
\end{abstract}

Keywords: exposure data, carcinogenic substances, acceptance concentration, tolerance concentration, benzo[a]pyrene, ethylenoxide, trichlorethene, butadiene. 


\section{Risk concept for carcinogenic hazardous substances and exposure-risk ratios}

Occupational exposures to carcinogenic substances occur in variety fields of industry. The risk strategy for carcinogenic substances in Germany entails a system for assessing hazards due to exposure at the workplace.

Under the German Dangerous Chemicals Ordinance (GefStoffV), employers are obliged to exclude risks to workers' safety and health during activities involving hazardous substances or to reduce such hazards to a minimum (Section 7 (4)). Where an occupational exposure limit (OEL) exists, it can be used as a basis for assessment of the risk presented by a hazardous substance. The GefStoffV defines an OEL as the concentration of a substance in the workplace atmosphere below which acute or chronic harmful effects to the health of workers need not generally be anticipated.

For carcinogenic hazardous substances with a genotoxic mechanism of action however, it is not generally possible to define a threshold value based upon occupational medical and toxicological findings which can serve as a basis for an OEL. An alternative method has been used to define maximum permissible exposure concentrations for these substances where their observance has been considered achievable by means of technical measures for the minimization of exposure (TRK technical reference concentrations). Since amendment of the GefStoffV in 2005, this is however no longer permissible, since limit values must now be set with reference to their impact upon human health. Consequently, a scientifically substantiated system for assessing carcinogenic substances at the workplace is now urgently needed which closes the resulting gap in the regulations. Against this background, the AGS Committee for Hazardous Substances in Germany developed the risk concept which, provided it proves effective in practice, is to be integrated into the GefStoffV [1].

A new aspect of this concept is that the measures required for worker protection are defined with reference to the associated increase in risk of occupationally induced cancer at a given exposure to the carcinogenic substance concerned during the working day. The concept essentially employs two risk limits: the acceptable risk of 4:10,000 (which is expected to be reduced to 4:100,000 in 2018, statistical probabilities: four additional cases of cancer per $1,000 / 10,000 / 100,000$ workers at 40 years of daily exposure), i.e. the level below which a risk is accepted (low risk), and the tolerable risk of $4: 1,000$, i.e. the level above which the risk is not tolerated (high risk). These two risk limits form the boundaries of the medium-risk band within which the risk is tolerated but the hazard must be reduced by means of a catalogue of measures. For this concept to be implemented, two atmospheric concentrations corresponding to the two risk limits stated above must be determined for each individual carcinogenic substance. These concentrations are described accordingly as the acceptable and tolerable concentrations. As described in the BekGS 910 announcement on hazardous substances, this can be achieved by the determining of exposure-risk ratios [2]. Data from human epidemiological studies or from animal testing may be used for this purpose. The AGS in Germany has already drawn up exposure- 
risk ratios for certain substances and has published the corresponding substancespecific concentrations in the BekGS 910 [3].

A comparison follows of the tolerable and acceptable concentrations of some of these substances with exposure data from the MGU Measurement system for exposure assessment of the German Social Accident Insurance Institutions. Exposure data from 2000 to 2010 were evaluated. The acceptable concentrations are abbreviated below as AC I $(4: 10,000)$ and AC II $(4: 100,000$, the target value for 2018), the tolerable concentration as TC. Unless specified further, the terms acceptable concentration, acceptable risk and mean risk refer to the currently applicable risk limit of 4:10,000.

\subsection{Determining, documentation and evaluation of exposure}

The workplace exposure measurement data which are evaluated below were determined and documented in accordance with the criteria of the MGU [4]. The MGU is a measurement system for exposure assessment which has been operated jointly for over four decades by the German statutory accident insurance institutions and the Institute for Occupational Safety and Health of the German Social Accident Insurance (IFA). It employs quality-assured procedures. The standards of the MGU are assured by a quality management system that essentially implements the requirements of EN ISO 9001. The test laboratories are operated in accordance with EN ISO 17025, "General requirements for the competence of testing and calibration laboratories". Descriptions of the measurement methods can be found in [5].

All data recorded in the MGU are stored in the MEGA database of measured data on workplace exposure to hazardous substances. Should discrete values fail to reach the analytical quantification limit (a. q.) of the measurement method used, half of the value is considered during statistical interpretation. The data in the MEGA exposure database can be evaluated statistically according to a range of selection criteria and evaluation strategies. Data collectives for example can be differentiated according to the associated industrial sector or working area. Mean values and percentiles are used below to describe the collectives. At an $x^{\text {th }}$ percentile (or $\mathrm{x} \%$ value), $\mathrm{x}$ percent of all available measured data lie below the value concerned, the remainder $(100-x)$ above it. Should the number of measured values below the analytical quantification limit (a. q.) be greater than the number of measured values represented by this cumulative frequency $(\mathrm{x} \%$ value), "a. q." is stated instead of the value in question. Collectives are evaluated only if at least ten measured values from at least five different companies exist.

\section{Substances with acceptable and tolerable concentrations}

At the time of production of the present publication, the BekGS 910 contains acceptable and tolerable concentrations for nine different substances. In accordance with the TRGS 400 technical rule for hazardous substances No 6.4 Paragraph 5, these concentrations are to be used as metrics for the risk assessment. For four of these substances, Table 1 states the number of workplace 
measured values with reference to the exposure which are documented in the MEGA database for the data period from 2000 to 2010. The table also shows the distribution of these measured values in percent in the areas of low, medium (light-grey shading) and high (dark-grey shading) risk. Measured values which lie below the relevant analytical quantification limit and have an analytical quantification limit greater than the acceptable concentration cannot be assigned to any risk range. The proportion of these measured values is also stated [6].

Table 1: $\quad$ Measurements from 2000 to 2010 with distribution in the risk band.

\begin{tabular}{|c|c|c|c|c|}
\hline & 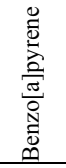 & 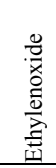 & 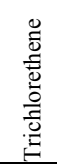 & 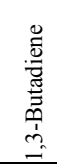 \\
\hline Number of measured data, total & 2.193 & 223 & 624 & 257 \\
\hline $\begin{array}{l}\text { Number of measured data with high risk (measurement value > } \\
\text { tolerance concentration (TC)) in \% }\end{array}$ & 20 & 21.5 & 40.5 & 0 \\
\hline $\begin{array}{l}\text { Number of measured data with average risk } \\
\text { (tolerance concentration } \geq \text { measurement value }>\text { acceptance } \\
\text { concentration }(\mathrm{AC} \mathrm{I}) \text { ) in \% }\end{array}$ & 118 & 35 & 9.9 & 0.4 \\
\hline $\begin{array}{l}\text { Number of measured data with low risk (measurement value } \leq \\
\text { acceptance concentration (AC I)) in } \%\end{array}$ & 6,2 & 25.6 & 45.7 & 0 \\
\hline Not allocated measurement values in \% & 62 & 17.9 & 3.9 & 99.6 \\
\hline
\end{tabular}

Substances exhibiting a high proportion of measured values with exposures above the acceptable concentration are benzo[a]pyrene, ethylene oxide and trichloroethylene. These substances are evaluated further; depending upon the available data, differentiation is made according to the duration of exposure, sectors of industry and working areas, kind of sampling, and whether a collection facility (exhaust) is present. The table shows percentiles in the medium and highrisk ranges by a light-grey and dark-grey background respectively. For 1,3butadiene, only a small number of available measured data lie above the acceptable concentration, or the available data are not sufficient. For this reason, the information is limited in these cases to a list of the sectors of industry and working areas for which measurement was performed. The evaluations of the exposure data are preceded by a brief description of the adverse effects to health of the carcinogenic substance concerned together with the concentrations (tolerable concentration, acceptable concentration) of the individual substances [3]. The TRK (technical exposure limit) values cited can be found in the 2004 version of the TRGS 900 technical rules [7]. The associated GHS classifications can be found in the GESTIS substance database [8]. 


\section{Benzo[a]pyrene}

\subsection{Carcinogenic action and risk limits}

Benzo[a]pyrene $(\mathrm{B}[\mathrm{a}] \mathrm{P})$ is a polycyclic aromatic hydrocarbon $(\mathrm{PAH})$. It is formed by incomplete combustion of carbon compounds, and always constitutes one component within a complex mixture of highly diverse PAHs. The PAHs include several hundred discrete compounds. The carcinogenic action of these mixtures is attributed primarily to the various polycyclic aromates consisting of four to seven rings. $\mathrm{B}[\mathrm{a}] \mathrm{P}$, being a highly carcinogenic example of these PAHs, served as an indicator substance during risk quantification. The exposure-risk ratio determined for $\mathrm{B}[\mathrm{a}] \mathrm{P}$ therefore relates to the "total $\mathrm{PAH}$ ". For this purpose, a PAH mixture was employed with a composition similar to the emissions from coking plants, gasworks and aluminium smelters. Like B[a]P, PAHs can be detected ubiquitously; their presence is often in the order of magnitude of the target value (for 2018) of the acceptable concentration of 4:100,000.

Epidemiological findings reveal a clear relationship between occupational $\mathrm{B}[\mathrm{a}] \mathrm{P} / \mathrm{PAH}$ exposure and the incidence of lung cancer. In addition, evidence suggests that exposed individuals face a greater risk of contracting bladder and skin tumours. A relationship is however also suspected between occupational $\mathrm{B}[\mathrm{a}] \mathrm{P} / \mathrm{PAH}$ exposure and the incidence of other tumour types. Like all PAHs, $\mathrm{B}[\mathrm{a}] \mathrm{P}$ is absorbed by inhalation, dermally and via the gastrointestinal tract.

The tolerable concentration $(4: 1,000)$ of $700 \mathrm{ng} / \mathrm{m}^{3}$ and the acceptable concentrations AC I $(4: 10,000)$ of $70 \mathrm{ng} / \mathrm{m}^{3}$ and AC II $(4: 100,000)$ of $7 \mathrm{ng} / \mathrm{m}^{3}$ are calculated from the exposure-risk ratio based upon the incidence for lung cancer. This represents a substantial reduction in the target maximum exposure quantities compared to the TRK (technical exposure limit) values, now suspended, of $5 \mu \mathrm{g} / \mathrm{m}^{3}$ for the production and charging of extruded pitch, furnace area of coking plants, and $2 \mu \mathrm{g} / \mathrm{m}^{3}$ for other areas [3]. Strict rules for the wearing of respiratory protective equipment in critical working areas were and still are in place however in the form of the TRGS 551 technical rules [9].

\subsection{Application of the exposure-risk ratio of $B[a] P$}

The overall carcinogenicity associated with exposure to PAHs containing $\mathrm{B}[\mathrm{a}] \mathrm{P}$ is dependent not only upon the concentrations of the discrete substances, but also upon the strength of their carcinogenic action. Acenaphthene, naphthalene, phenanthrene and pyrene are assumed to be much weaker in their action than $\mathrm{B}[\mathrm{a}] \mathrm{P}$. Conversely, certain dibenzopyrenes are considered to be ten times as carcinogenic [10]. Even minor fluctuations in the concentration of these highly carcinogenic substances could therefore have a substantial influence upon their hazard potential.

At present, 16 PAHs are detected on a specimen holder as standard in the MGU. This enables the relative distribution of the individual PAHs in each sample to be calculated compared to the $\mathrm{B}[\mathrm{a}] \mathrm{P}$ indicator component (provided the measured values lie above the analytical limit of detection). The figure shows 


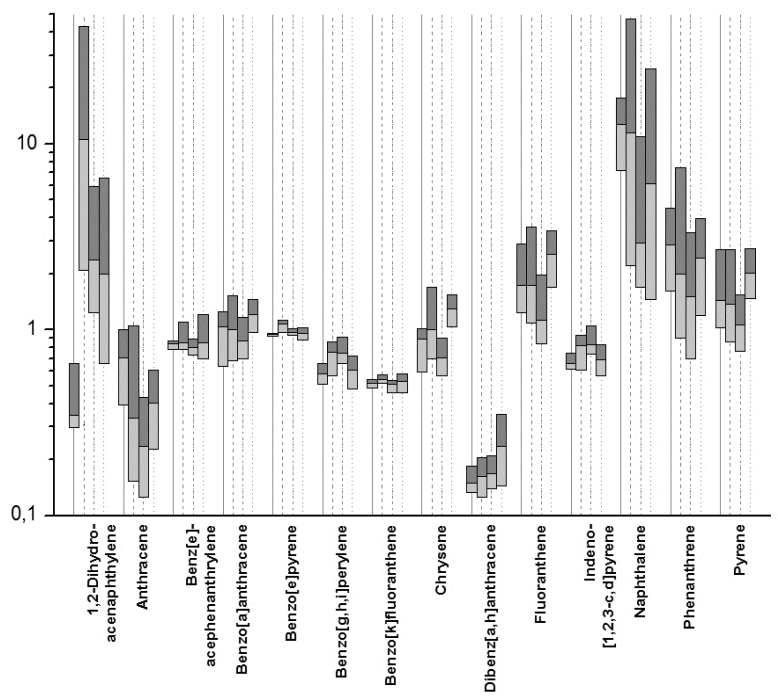

Figure 1: Concentration in relation to benzo[a]pyrene.

the 25th, 50th and 75th percentiles of the concentrations of the measured PAHs as multiples of the $\mathrm{B}[\mathrm{a}] \mathrm{P}$ concentrations measured on the same specimen holders [11].

The evaluation was performed separately for coking plant emissions (unbroken vertical lines) and for the measurements from the three sectors of construction (dots), electrical engineering/precision engineering/optics (dots/dashes) and the stone and ceramics industry (short dashes). It can be seen that the ratio of the atmospheric concentrations of many PAHs to the concentration of $\mathrm{B}[\mathrm{a}] \mathrm{P}$ measured at the same time are in similar orders of magnitude in the different sectors. The ranges are greatest here for substances which generally have a lower strength of action (acenaphthene, naphthalene, phenanthrene, pyrene). For coking plant emissions, it can be seen that for a given $\mathrm{B}[\mathrm{a}] \mathrm{P}$ concentration, the additional proportion of the exposure accounted for by other PAHs is often comparable to or if anything lower than that in other sectors. Accordingly, the available data in no way warrant the conclusion that when $\mathrm{B}[\mathrm{a}] \mathrm{P}$ is used as an indicator substance for the evaluation of $\mathrm{PAH}$ exposure in sectors other than coking plants, gasworks and aluminium smelters, the risk for the employees in these sectors is over-evaluated.

\subsection{Exposure}

\subsubsection{Available data}

The following descriptions of exposure (Table 2) are based upon the 2,012 shiftbased measured values from among the 2,193 measured values in total from the data period under evaluation; the mean duration of exposure at the workplaces at 
which measurement was performed was 7.99 hours. 662 measured values are above the analytical quantification limit (a. q). 246 of these (12\%) in the medium-risk and $414(20 \%)$ in the high-risk range. Only 132 measured values can be assigned clearly to the low-risk exposure band. 1,359 measured values fail to exceed the corresponding analytical quantification limit, which is generally higher than the acceptable concentration ( $91 \%$ of the measured values are below the analytical quantification limit; in only five cases is the analytical quantification limit also higher than the tolerable concentration). The actual proportion of exposure associated with medium risk will therefore be substantially higher. Accordingly, under no circumstances should a harmless exposure level generally be assumed for collectives for which statistical parameters are not stated owing to the high proportion of measured values below the analytical quantification limit.

Table 2: $\quad$ Data of benzo[a]pyrene.

\begin{tabular}{|c|c|c|c|c|c|c|c|c|}
\hline Data set & 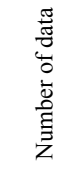 & 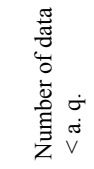 & 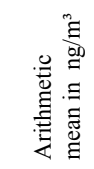 & 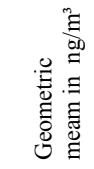 & 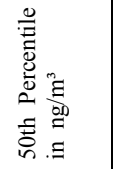 & 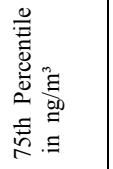 & 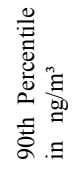 & 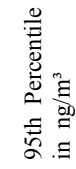 \\
\hline Total & 2021 & 1359 & 4130 & 182 & a. q. ! & $360+$ & 2700 & 11500 \\
\hline $\begin{array}{l}\text { Stationary } \\
\text { sampling }\end{array}$ & 1282 & 1007 & 3500 & 116 & a. q. ! & a. q. & 898 & 2790 \\
\hline $\begin{array}{l}\text { Personal } \\
\text { sampling }\end{array}$ & 739 & 352 & 5230 & 400 & $200+$ & 1380 & 7710 & 23700 \\
\hline $\begin{array}{l}\text { Working area } \\
\text { with local } \\
\text { exhaust } \\
\text { ventilation }\end{array}$ & 733 & 440 & 1750 & 214 & a. q. & 638 & 2370 & 5500 \\
\hline $\begin{array}{l}\text { Working area } \\
\text { without local } \\
\text { exhaust } \\
\text { ventilation }\end{array}$ & 718 & 503 & 4990 & 184 & a. q. ! & 295 & 5060 & 23400 \\
\hline
\end{tabular}

$+\quad$ The distribution value is below the largest analytical quantification limit in the data set.

! The number of measured values below the analytical quantification limit (a. q.) is greater than the number for measured values represented by this cumulative frequency value. No concentration is therefore given for this cumulative frequency value.

At $2,700 \mathrm{ng} / \mathrm{m}^{3}$, the 90 th percentile of all $\mathrm{B}[\mathrm{a}] \mathrm{P}$ exposure measurements is substantially above the tolerable concentration of $700 \mathrm{ng} / \mathrm{m}^{3}$. The 75 th percentile exceeds the acceptable concentration of $70 \mathrm{ng} / \mathrm{m}^{3}$ by over a factor of five. If only the measurements obtained by means of personal sampling are considered, even the 50 th percentile, at $200 \mathrm{ng} / \mathrm{m}^{3}$, is in the medium-risk range.

\subsubsection{Sectors of industry}

Exposures exhibiting statistical parameters in the high-risk range were measured in numerous sectors of industry (Table 3 ). 
Table 3: $\quad$ Benzo[a]pyrene - sector of industry.

\begin{tabular}{|c|c|c|c|c|c|c|c|c|c|c|c|c|}
\hline Data set & 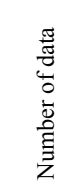 & 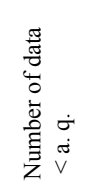 & 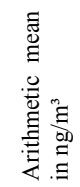 & 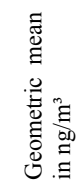 & 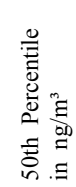 & & 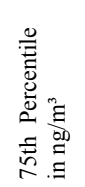 & & 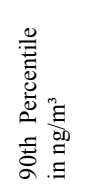 & & 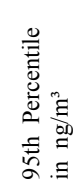 & \\
\hline $\begin{array}{l}\text { Waste disposal and } \\
\text { buildings cleaning }\end{array}$ & 145 & 114 & 608 & 74.2 & a. q. & $!$ & a. q. & $!$ & 385 & + & 1450 & \\
\hline Construction sector & 319 & 110 & 22100 & 1100 & 885 & & 15800 & & 47300 & & 89400 & \\
\hline Chemical industry & 48 & 40 & 270 & 103 & a. q. & $!$ & a. q. & $!$ & 276 & + & 544 & + \\
\hline $\begin{array}{l}\text { Electrical } \\
\text { engineering, } \\
\text { precision } \\
\text { engineering, optics }\end{array}$ & 198 & 54 & 1890 & 603 & 720 & & 1790 & & 5180 & & 6540 & \\
\hline $\begin{array}{l}\text { Energy } \\
\text { development }\end{array}$ & 65 & 28 & 1780 & 428 & 440 & + & 1210 & & 5320 & & 7400 & \\
\hline Glas industry & 50 & 50 & 79.4 & 78.2 & a. q. & $!$ & a. q. & $!$ & a. q. & ! & a.q. & $!$ \\
\hline $\begin{array}{l}\text { Rubber } \\
\text { manufacture }\end{array}$ & 21 & 21 & 89.8 & 71.5 & a. q. & $!$ & a. q. & $!$ & a. q. & $!$ & a. q. & $!$ \\
\hline Wood and paper & 37 & 34 & 180 & 81.6 & a. q. & $!$ & a. q. & $!$ & a. q. & $!$ & 270 & \\
\hline Plastic industry & 28 & 27 & 78.9 & 75.2 & a. q. & $!$ & a. q. & $!$ & a. $\mathrm{q}$. & $!$ & a. q. & $!$ \\
\hline $\begin{array}{l}\text { Processing metals } \\
\text { and mechanical } \\
\text { engineering }\end{array}$ & 363 & 346 & 830 & 80.7 & a. q. & $!$ & a. q. & $!$ & a. q. & $!$ & a. q. & $!$ \\
\hline $\begin{array}{l}\text { Manufacture of } \\
\text { metals }\end{array}$ & 261 & 202 & 724 & 113 & a. $\mathrm{q}$. & $!$ & a. q. & $!$ & 449 & & 1400 & \\
\hline Shipping & 73 & 73 & 55.9 & 38.2 & a. q. & $!$ & a. q. & $!$ & a. q. & $!$ & a. q. & $!$ \\
\hline $\begin{array}{l}\text { Stone and ceramics } \\
\text { industry }\end{array}$ & 338 & 189 & 622 & 190 & a. q. & $!$ & 465 & & 1600 & & 2500 & \\
\hline Transport & 109 & 107 & 62.1 & 45 & a. q. & $!$ & a. q. & $!$ & a. q. & $!$ & a. q. & $!$ \\
\hline
\end{tabular}

Explanations, see table 2

The 50th percentile of the values measured in the construction sector and in the sectoral group of electrical engineering, precision engineering and optics lie above the tolerable concentration. In waste disposal and buildings cleaning, energy development, manufacture of metals and the stone and ceramics industry, this is still the case at least for the 95th percentile. Foci of medium- and high-risk exposure are seen in the following sectors: work in contaminated areas (waste disposal and buildings cleaning), redevelopment, corrosion protection, construction of stoves and industrial ovens (construction sector), general working areas in electrical engineering (the sectoral group of electrical engineering, precision engineering and optics), coking plants (energy development), aluminium smelters, foundries and electric steel works (metals production), and the manufacture of refractory goods (stone and ceramics industry). 


\subsubsection{Working areas}

Table 4 shows groups of working areas that can be formed from the available exposure data. Where possible, these groups also have been formed based upon personal measurements, which generally exhibit higher measured values than the undifferentiated collective. It can be seen that workplaces associated with an

Table 4: $\quad$ Benzo[a]pyrene - working area.

\begin{tabular}{|c|c|c|c|c|c|c|c|c|c|c|c|}
\hline Data set & 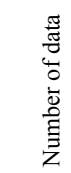 & 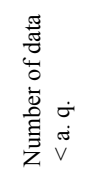 & 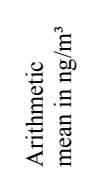 & 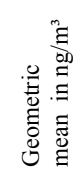 & 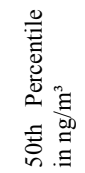 & & 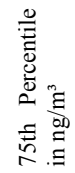 & & 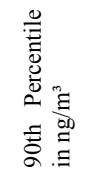 & & 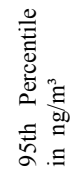 \\
\hline $\begin{array}{l}\text { Remediation, } \\
\text { redevelopment } \\
\text { work }\end{array}$ & 104 & 76 & 3210 & 103 & a. q. & $!$ & 140 & + & 3570 & & 11100 \\
\hline $\begin{array}{l}\text { Remediation, } \\
\text { redevelopment } \\
\text { work } \\
\text { (personal sampling) }\end{array}$ & 24 & 7 & 12800 & 1310 & 700 & & 7160 & & 47700 & & 65900 \\
\hline $\begin{array}{l}\text { Construction, } \\
\text { miscellaneous work }\end{array}$ & 25 & 3 & 8680 & 1610 & 2010 & & 7310 & & 24400 & & 38500 \\
\hline Preparing for firing & 56 & 12 & 1400 & 543 & 730 & & 1400 & & 2600 & & 3760 \\
\hline Grinding & 36 & 19 & 2420 & 192 & a. q. & $!$ & 490 & & 6140 & & 11200 \\
\hline $\begin{array}{l}\text { Grinding } \\
\text { personal sampling) }\end{array}$ & 11 & 7 & 5960 & 351 & a. q. & $!$ & 2140 & & 23300 & & 28200 \\
\hline Casting, smelting & 150 & 128 & 1040 & 104 & a. q. & $!$ & a. q. & $!$ & 180 & + & 1430 \\
\hline $\begin{array}{l}\text { Casting, smelting } \\
\text { (personal sampling) }\end{array}$ & 30 & 22 & 3940 & 185 & a. q. & $!$ & 110 & + & 4570 & & 6260 \\
\hline Hardening & 31 & 31 & 68.9 & 65.3 & a. q. & $!$ & a. q. & $!$ & a. q. & ! & a. q. \\
\hline Mixing & 104 & 22 & 2350 & 659 & 680 & & 2520 & & 5440 & & 7980 \\
\hline $\begin{array}{l}\text { Mixing } \\
\text { (personal sampling) }\end{array}$ & 69 & 3 & 3330 & 1340 & 1280 & & 3960 & & 6440 & & 10400 \\
\hline Installation & 23 & 21 & 66.7 & 60.8 & a. q. & ! & a. q. & ! & a. q. & ! & 149 \\
\hline Kiln & 49 & 38 & 307 & 117 & a. $\mathrm{q}$. & $!$ & a. q. & $!$ & 793 & & 1090 \\
\hline $\begin{array}{l}\text { Kiln } \\
\text { (personal sampling) }\end{array}$ & 23 & 15 & 493 & 148 & a. q. & $!$ & 295 & & 1090 & & 1950 \\
\hline Pressing & 190 & 94 & 770 & 257 & 150 & + & 905 & & 2400 & & 4110 \\
\hline $\begin{array}{l}\text { Pressing } \\
\text { (personal sampling) }\end{array}$ & 96 & 23 & 1280 & 560 & 770 & & 1300 & & 3700 & & 5010 \\
\hline Cleaning & 20 & 15 & 1090 & 271 & a. q. & $!$ & 670 & + & 2700 & & 5580 \\
\hline $\begin{array}{l}\text { Cleaning } \\
\text { (personal sampling) }\end{array}$ & 12 & 9 & 892 & 278 & a. q. & $!$ & 670 & 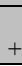 & 1750 & & 3340 \\
\hline Forging & 26 & 21 & 190 & 108 & a. q. & $!$ & a. q. & $!$ & 388 & & 682 \\
\hline Welding & 99 & 99 & 70.4 & 67 & a. q. & $!$ & a. q. & $!$ & a. q. & ! & a. q. \\
\hline $\begin{array}{l}\text { Impact drilling, } \\
\text { chiselling }\end{array}$ & 37 & 2 & 10400 & 1960 & 1290 & & 15700 & & 34200 & & 37700 \\
\hline $\begin{array}{l}\text { Impact drilling, } \\
\text { chiselling } \\
\text { (personal sampling) }\end{array}$ & 28 & 2 & 12000 & 2320 & 1430 & & 16900 & & 35100 & & 40500 \\
\hline $\begin{array}{l}\text { Control / operating } \\
\text { panel }\end{array}$ & 45 & 21 & 1400 & 354 & 320 & & 1070 & & 3640 & & 5360 \\
\hline $\begin{array}{l}\text { Control / operating } \\
\text { panel } \\
\text { (personal sampling) }\end{array}$ & 32 & 8 & 1930 & 636 & 690 & & 1300 & & 4960 & & 5440 \\
\hline Blasting & 100 & 13 & 59600 & 6940 & 19400 & & 58500 & & 141000 & & 300000 \\
\hline $\begin{array}{l}\text { Blasting } \\
\text { (personal sampling) }\end{array}$ & 44 & 10 & 43100 & 3510 & 2500 & & 33300 & & 86400 & & 127000 \\
\hline
\end{tabular}

Explanations, see table 2 
elevated health risk frequently involve mechanical tasks: blasting (various methods) in corrosion protection, milling in road construction, impact drilling and chiselling during redevelopment work, and mixing and pressing during the manufacture of electrical carbon and refractory goods. This is also the case for the groups of redevelopment/remediation and of construction/miscellaneous work. Values above the acceptable concentration for the control/operating panel group are measured for the most part in coking plants.

\section{Ethylene oxide}

\subsection{Carcinogenic action and risk limits}

Ethylene oxide is distributed well within the body following intake by inhalation. Owing to its genotoxic properties, it is therefore suspected of being able to exert a carcinogenic effect in a number of tissues. The exposure-risk ratio was based upon the formation of lung tumours in experiments performed on mice. The incidence of brain tumours in rats following inhalative administration is also considered relevant to human beings. The tolerance risk $(4: 1,000)$ equates to an approximate tolerable concentration of $2 \mathrm{mg} / \mathrm{m}^{3}(=1.1 \mathrm{ppm})$, the acceptable risk to approximate acceptable concentrations of $0.2 \mathrm{mg} / \mathrm{m}^{3}(=0.11 \mathrm{ppm})$ for AC I and $0.02 \mathrm{mg} / \mathrm{m}^{3}(=0.01 \mathrm{ppm})$ for AC II. Like the tolerable concentration, the 2004 TRK value was in the order of $2 \mathrm{mg} / \mathrm{m}^{3}$ [2].

\subsection{Exposure values}

\subsubsection{Available data}

Shift-based and non-shift-based values are relevant to ethylene oxide (Table 5).

Table 5: $\quad$ Data of ethylenoxide.

\begin{tabular}{|c|c|c|c|c|c|c|c|c|c|c|}
\hline Data set & 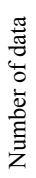 & 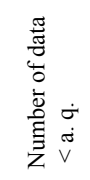 & 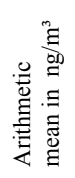 & 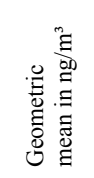 & 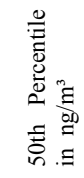 & & 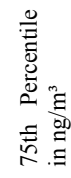 & & 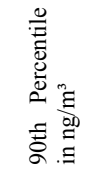 & 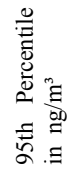 \\
\hline \multicolumn{11}{|c|}{ shift: exposure duration $\geq 6$ Stunden (average exposure duration 8.083 hours) } \\
\hline Total & $\begin{array}{l}1 \\
4 \\
4\end{array}$ & 55 & 3.351 & 0.479 & 0.4 & + & 1 & + & 4 & 8 \\
\hline $\begin{array}{l}\text { Stationary } \\
\text { sampling }\end{array}$ & $\begin{array}{l}8 \\
2\end{array}$ & 25 & 2.234 & 0.533 & 0.4 & + & 1.25 & & 4 & 7.8 \\
\hline $\begin{array}{l}\text { Personal } \\
\text { sampling }\end{array}$ & $\begin{array}{l}6 \\
2\end{array}$ & 30 & 4.83 & 0.416 & 0.3 & + & 0.9 & + & 2.48 & 8.18 \\
\hline \multicolumn{11}{|c|}{ Non-shift-based: exposure duration < 6 hours (average exposure duration 1.465 hours) } \\
\hline Total & $\begin{array}{l}7 \\
6\end{array}$ & 30 & 12.30 & 1.282 & & + & 3 & & 9.76 & 28.8 \\
\hline
\end{tabular}

Explanations, see table 2 
Altogether, 144 shift-based values are available, with a mean exposure duration of approximately 8 hours; substantial differences in the measurement results are not observed between static and personal sampling. Even the 50th percentile values are above the acceptable concentration; the 90th percentile values (between 2.5 and $4 \mathrm{mg} / \mathrm{m}^{3}$, depending upon the form of sampling) indicate exposure in the high-risk range. Evaluation of the 76 items of non-shiftbased measured data, for which the mean exposure duration was approximately 1.5 hours, reveals that overall the values of the corresponding percentiles are higher and that the tolerable concentration is often exceeded several times. The 90th percentile value for example is almost $10 \mathrm{mg} / \mathrm{m}^{3}$. Atmospheric concentrations of ethylene oxide in this order of magnitude may represent a high risk even at short durations of exposure. In the associated working areas, ethylene oxide is used for sterilization purposes, or is released for example from products (medical devices) in storage which had previously been fumigated at a different location for the purpose of sterilization.

\subsubsection{Sectors of industry and working areas}

The majority of exposure measurements were performed in plants in the chemical industry and the electrical engineering, precision engineering and optics group of sectors. In both cases, affected working areas are primarily associated with the sterilization and storage of medical devices. For the values measured for sterilization work, the 90th percentile lies above the tolerable concentration; for those for storage work, this is also the case for the 75th percentile. The statistical parameters are summarized in Table 6.

Table 6: $\quad$ Ethylenoxide - sector of industry and working area.

\begin{tabular}{|c|c|c|c|c|c|c|c|c|c|c|}
\hline Data set & 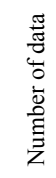 & 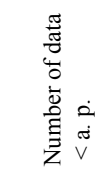 & 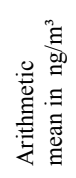 & 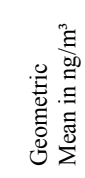 & 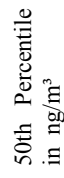 & & 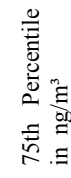 & & 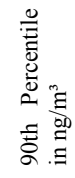 & 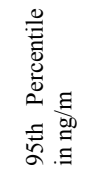 \\
\hline $\begin{array}{l}\text { Chemical } \\
\text { industry }\end{array}$ & 79 & 31 & 3.765 & 0.418 & 0.35 & + & 0.8 & + & 2.61 & 6 \\
\hline $\begin{array}{l}\text { Electrical } \\
\text { engineering, } \\
\text { precision } \\
\text { engineering, } \\
\text { optics }\end{array}$ & 25 & 3 & 3.84 & 1.0464 & 1 & & 2.3 & & 4.25 & 24.375 \\
\hline Storage & 47 & 11 & 3.043 & 0.885 & 1 & & 2.6 & & 6.6 & 8 \\
\hline $\begin{array}{l}\text { Sterilization } \\
\text { work }\end{array}$ & 41 & 14 & 6.485 & 0.584 & 0.45 & + & 0.875 & + & 2.63 & 5.86 \\
\hline
\end{tabular}

Explanations, see table 2 


\section{Trichloroethene}

\subsection{Carcinogenic action and risk limits}

Trichloroethene has a genotoxic effect upon the kidneys. In addition, inducing of liver cancer and non-Hodgkin's lymphoma tumours owing to local genotoxicity cannot be excluded. The risk limits were derived from epidemiological studies and experimental findings on male rats for the incidence of kidney tumours. The tolerance risk $(4: 1,000)$ equates to an approximate tolerable concentration of $60 \mathrm{mg} / \mathrm{m}^{3}$, the acceptable risk to approximate acceptable concentrations of $33 \mathrm{mg} / \mathrm{m}^{3}$ for AC I and $3.3 \mathrm{mg} / \mathrm{m}^{3}$ for AC II. The TRK technical reference concentration was $165 \mathrm{mg} / \mathrm{m}^{3}$. In the case of contact of liquid trichloroethene with the skin, the dermal intake path yields a clear contribution to the exposure [3].

\subsection{Exposure values}

\subsubsection{Available data}

Altogether, a total of 624 measured values were evaluated (Table 7).

Measurements at workplaces at which the employees were exposed for only part of the time are also available for trichloroethene. Evaluation of these nonshift-based measured values yields a 75 th percentile of $285 \mathrm{mg} / \mathrm{m}^{3}$. In

Table 7: $\quad$ Data of trichlorethene.

\begin{tabular}{|c|c|c|c|c|c|c|c|c|}
\hline Data set & 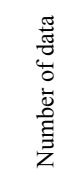 & 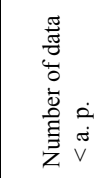 & 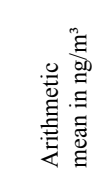 & 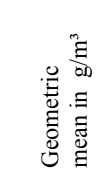 & 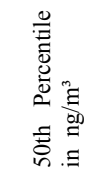 & 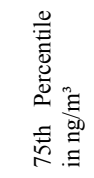 & 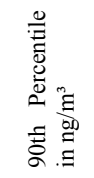 & 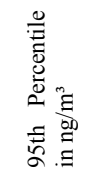 \\
\hline \multicolumn{9}{|c|}{ Shift: exposure duration $\geq 6$ hours (average exposure duration 7.881 hours) } \\
\hline Total & 469 & 112 & 110.001 & 22.556 & $24+$ & 92.75 & 192.2 & 308.4 \\
\hline $\begin{array}{l}\text { Stationary } \\
\text { sampling }\end{array}$ & 240 & 76 & 125.778 & 17.338 & $17+$ & 82 & 177 & 293 \\
\hline $\begin{array}{l}\text { Personal } \\
\text { sampling }\end{array}$ & 229 & 36 & 93.467 & 29.718 & $37+$ & 94 & 201.1 & 339.95 \\
\hline $\begin{array}{l}\text { Working area } \\
\text { with local exhaust } \\
\text { ventilation }\end{array}$ & 273 & 69 & 109.973 & 20.603 & 21 & 87.25 & 160 & 237.1 \\
\hline $\begin{array}{l}\text { Working area } \\
\text { without local } \\
\text { exhaust } \\
\text { ventilation }\end{array}$ & 98 & 23 & 133.325 & 28.506 & $30+$ & 126.5 & 283.2 & 701.8 \\
\hline \multicolumn{9}{|c|}{ Non-shift-based: exposure duration < 6 hours (average exposure duration 2,182 hours) } \\
\hline Total & 103 & 17 & 282.143 & 64.564 & 87 & 284.5 & 543.7 & 1089.35 \\
\hline \multicolumn{9}{|c|}{ Exposure peaks (no exposure duration documented) } \\
\hline Total & 52 & 20 & 186.288 & 75.898 & 78 & 179 & 422.2 & 816 \\
\hline
\end{tabular}

Explanations, see table 2 
consideration of the mean exposure duration of around two hours, a high risk cannot be excluded at these and higher concentrations of hazardous substances. Workplaces primarily affected are laboratory workplaces in educational establishments and asphalt laboratories. The same applies to further 52 measured values which were documented as exposure peaks. Of the 469 shift-based measured values (mean exposure duration: 7.881 hours), 112 are below the analytical quantification limit. The 75 th percentiles are substantially above the tolerable concentration. The following differentiations by sector of industry and working area relate only to the shift-based measurement data.

\subsubsection{Sectors of industry}

The 75th percentiles of all sectoral groups (Table 8) are above the acceptable concentration.

Table 8: $\quad$ Trichlorethene - sector of industry.

\begin{tabular}{|c|c|c|c|c|c|c|c|c|}
\hline Data set & 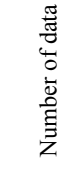 & 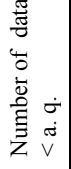 & 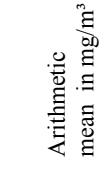 & 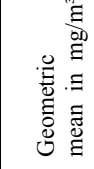 & 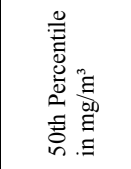 & 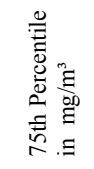 & 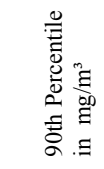 & 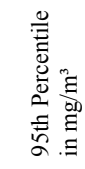 \\
\hline $\begin{array}{l}\text { Construction } \\
\text { sector }\end{array}$ & 19 & 5 & 325.874 & 84.662 & 167.5 & 386.75 & 701.8 & 773 \\
\hline $\begin{array}{l}\text { Educational } \\
\text { establish- } \\
\text { ments }\end{array}$ & 81 & 4 & 59.94 & 26.621 & 45 & 75 & 112.7 & 228.5 \\
\hline $\begin{array}{l}\text { Electrical } \\
\text { engineering, } \\
\text { precision } \\
\text { engineering, } \\
\text { optics }\end{array}$ & 18 & 8 & 43.275 & 11.127 & 6 & 48.5 & 116.8 & 145.6 \\
\hline $\begin{array}{l}\text { Rubber } \\
\text { manufacture }\end{array}$ & 28 & 0 & 274.357 & 80.649 & 110 & 270 & 773.8 & 1192.6 \\
\hline $\begin{array}{l}\text { Plastic } \\
\text { industry }\end{array}$ & 22 & 4 & 44.925 & 9.422 & 13 & 39.5 & 79.8 & 88.2 \\
\hline $\begin{array}{l}\text { Processing } \\
\text { metals and } \\
\text { mechanical } \\
\text { engineering }\end{array}$ & 50 & 14 & 38.431 & 14.723 & 11 & 60 & 98 & 128.5 \\
\hline $\begin{array}{l}\text { Stone and } \\
\text { ceramics } \\
\text { industry }\end{array}$ & 203 & 54 & 75.0667 & 24.874 & 21 & 109.25 & 169.5 & 256 \\
\hline
\end{tabular}

Explanations, see table 2

The highest exposure levels are found in the construction sector and rubber manufacture. All 81 measurements in educational establishments relate to laboratory workplaces. The focus of the measurement activities in the stone and ceramics industry ( 173 data records among a total of 203 measured values) lay in asphalt plants and for the most part also concerned measurements in these plants' laboratories. 


\subsubsection{Working areas}

Several groups can be formed from the various working areas (Table 9); laboratory workplaces are significantly more numerous than the other groups.

Table 9: $\quad$ Trichlorethene - working area.

\begin{tabular}{|c|c|c|c|c|c|c|c|c|}
\hline Data set & 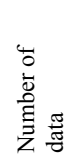 & 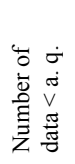 & 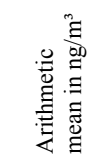 & 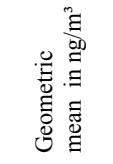 & 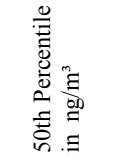 & 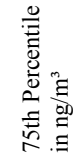 & 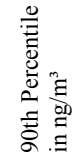 & 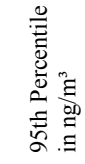 \\
\hline $\begin{array}{l}\text { Fat removal } \\
\text { system }\end{array}$ & 36 & 5 & 82.715 & 21.741 & 19 & 57 & 114.4 & 163.2 \\
\hline $\begin{array}{l}\text { Fat removal } \\
\text { system } \\
\text { (personal } \\
\text { sampling) }\end{array}$ & 21 & 4 & 100.502 & 19.215 & 13.5 & 48.75 & 112.9 & 127.35 \\
\hline Gluing & 28 & 2 & 136.732 & 31.238 & 38 & 123 & 319.2 & 642.8 \\
\hline $\begin{array}{l}\text { Gluing } \\
\text { (personal } \\
\text { sampling) }\end{array}$ & 18 & 2 & 160.372 & 30.818 & 23 & 111 & 555.6 & 751.9 \\
\hline $\begin{array}{l}\text { Laboratory } \\
\text { (total) }\end{array}$ & 248 & 52 & 85.245 & 29.7 & 37 & 104 & 173 & 304.4 \\
\hline $\begin{array}{l}\text { Laboratory } \\
\text { (total) } \\
\text { (personal } \\
\text { sampling }\end{array}$ & 129 & 20 & 72.259 & 32.718 & 45 & 91.75 & 156.8 & 237.2 \\
\hline $\begin{array}{l}\text { Laboratory } \\
\text { (asphalt and } \\
\text { construction } \\
\text { material) }\end{array}$ & 156 & 42 & 81.625 & 26.119 & 23 & 112 & 171.4 & 270.6 \\
\hline $\begin{array}{l}\text { Laboratory } \\
\text { (asphalt and } \\
\text { construction } \\
\text { material) } \\
\text { (personal } \\
\text { sampling) }\end{array}$ & 63 & 15 & 66.192 & 25.587 & 23.5 & 109.75 & 154.2 & 171.85 \\
\hline $\begin{array}{l}\text { Laboratory } \\
\text { (scientific } \\
\text { research) }\end{array}$ & 71 & 4 & 61.79 & 35.831 & 46.5 & 75.25 & 112.5 & 213.5 \\
\hline $\begin{array}{l}\text { Laboratory } \\
\text { (scientific } \\
\text { research) } \\
\text { (personal } \\
\text { sampling) }\end{array}$ & 55 & 2 & 70.596 & 43.499 & 51 & 83.5 & 131 & 231.25 \\
\hline $\begin{array}{l}\text { Surface } \\
\text { treatment }\end{array}$ & 23 & 4 & 215.783 & 51.00935 & 53 & 234.75 & 686.5 & 715.3 \\
\hline $\begin{array}{l}\text { Surface } \\
\text { treatment } \\
\text { (personal } \\
\text { sampling) }\end{array}$ & 13 & 4 & 267.385 & 45.151 & 49.5 & 357.5 & 699.1 & 940.95 \\
\hline Cleaning & 18 & 5 & 22.231 & 8.342 & 10 & 27.5 & 45.2 & 94.4 \\
\hline
\end{tabular}

Explanations, see table 2. 
The acceptable concentration is exceeded by over $50 \%$ of the measurements in the working area groups of gluing, laboratory and surface treatment; over $25 \%$ of the measured values in these working areas are also substantially above the tolerable concentration.

\section{Butadiene (1, 3-butadiene)}

\subsection{Carcinogenic action and risk limits}

Owing to its genotoxic properties, 1,3-butadiene is carcinogenic. Numerous epidemiological studies exist concerning the carcinogenicity of 1,3-butadiene; these were performed on workers in both the synthetic rubber and monomer production sectors. An increase in the incidence of leukaemia and the formation of malignant lymphatic and hematopoietic tissue was observed among the affected individuals. The exposure-risk ratio was formed based upon leukaemia fatality rates in a North American cohort of workers involved in synthetic rubber production. It reveals substance-specific concentrations of $5 \mathrm{mg} / \mathrm{m}^{3}$ for the tolerable risk and of $0.5 \mathrm{mg} / \mathrm{m}^{3}$ and $0.05 \mathrm{mg} / \mathrm{m}^{3}$ for the acceptable risks I and II respectively. The upper exposure limits governed by the TRK technical reference concentration values were around $34 \mathrm{mg} / \mathrm{m}^{3}$ for post-polymerization processing and for charging, and around $11 \mathrm{mg} / \mathrm{m}^{3}$ for other cases [3].

\subsection{Exposure values}

For the data period under evaluation, 257 measured values were documented for 1,3-butadiene exposure. Of these, only one measured value lay above the analytical quantification limit, which varies according to the duration and volume of sampling and is generally around $1 \mathrm{mg} / \mathrm{m}^{3}$. Accordingly, it can be concluded for the measured values below the analytical quantification limit only that the tolerable concentration is not exceeded. A medium risk caused by exposure to 1,3-butadiene cannot therefore be excluded. Further evaluation of the measured values would not therefore appear beneficial. Consequently, only the sectors of industry and working areas in which sampling was performed are listed.

- The most common sectors are: the plastics industry ( 94 - number of measurements); metalworking and machine construction (49); electrical engineering, precision engineering, optics (30); leather industry, textile industry (28).

- $\quad$ The most frequent working areas are: extruders (34); mouldings (46); plastics welding (10); laboratory (9).

\section{Discussion}

The exposure-risk ratios of the BekGS 910 serve as new assessment metrics for exposure to carcinogenic substances. Comparison of the resulting risk limits with the exposure data from the MEGA database enables workplaces to be identified 
at which the workers are potentially exposed to a risk higher than the acceptable risk of contracting occupational cancer. Over $50 \%$ of the measured values for ethylene oxide and trichloroethene are for example seen to lie above the respective acceptable concentrations (AC I). In many cases, the tolerable concentration (TC) is also exceeded by the 75th percentiles and in some cases even by the 50th percentiles of sector of industry or working area groups.

Exposure to $\mathrm{B}[\mathrm{a}] \mathrm{P}$ and $\mathrm{PAHs}$ is of particular relevance in these analyses, since in some cases it arises inadvertently and unmonitored, which makes emission-reducing measures difficult. Even though the acceptable and tolerable concentrations employed for evaluation were explicitly formulated only for emissions at coking plants, gasworks and aluminium smelters, exposure to $\mathrm{B}[\mathrm{a}] \mathrm{P}$ exceeding these concentrations should be taken seriously, since as has been shown, the distribution patterns of PAH exposure in the sectors studied do not differ fundamentally from those at coking plant workplaces. Unfortunately, the atmospheric concentrations were not routinely recorded for the PAHs suggested as having a stronger carcinogenic effect than that of $\mathrm{B}[\mathrm{a}] \mathrm{P}$ (such as various dibenzopyrenes [10]. The reason for this is that the individual compounds analysed as being representative of the substance group are selected with reference to the list of "priority pollutants" [12] of the United States Environmental Protection Agency (US EPA), and that this selection is based upon environmental toxicology. The PAHs relevant to routine measurement are however currently the subject of discussion [10]. Accordingly, until new findings are available, exposure should be reduced and adequate measures taken to protect the workers at workplaces notable for increased $\mathrm{B}[\mathrm{a}] \mathrm{P}$ concentrations.

The examples described here show that the exposure situation and where appropriate also the state of the art must be determined with reference to the industrial sector and in some cases to the specific process. As a general rule, existing measures which contribute to the values remaining below the acceptable concentration should be maintained in accordance with the principle of minimizing exposure. Regular monitoring should be performed in order to prevent the exposure situation from deteriorating [13]. The in-plant measures to be taken in response to exceeding of the acceptable concentration are of key importance in industrial practice. These measures concern the consideration of substitute substances and comprise technical, organizational and occupational medical measures.

With regard to the exposure data presented here, and also in consideration of exposure-risk ratios that have yet to be formulated, it is seen that in many cases, the atmospheric concentrations to be monitored require substantially lower the analytical quantification limits than those routinely achieved at present. This particularly applies to 1,3-butadiene, for which the measured values are almost all below the analytical quantification limit, which in turn however is higher than the acceptable concentration. Over $60 \%$ of the measurements of $\mathrm{B}[\mathrm{a}] \mathrm{P}$, too, cannot be assigned reliably to the low-risk range. The performance of measurements in the range of the acceptable concentration presents problems. Consideration must be given to adjusting existing measurement methods to the requirements, or to developing new methods [13]. 
Acceptable concentrations may under certain circumstances be so low as to lie below the external background exposure level. Guidance on risk assessment is required in this case. This could ultimately result in background exposure not caused by the employer being deducted for assessment purposes [13].

The procedure to be followed when several substances occur simultaneously at a workplace must also be discussed. Can the effect of substances with the same target organ be linked additively [13]?

For some substances for which exposure-risk ratios exist, few or no exposure data are available. In these cases, it is advisable to examine whether these gaps in the knowledge concerning possible risks to the workers can be closed, for example by the imposition of measurement programmes.

\section{References}

[1] Bekanntmachung zu Gefahrstoffen: Risikowerte und Exposition-RisikoBeziehungen für Tätigkeiten mit krebserzeugenden Gefahrstoffen (Bek. GS 910). Ausg. 6/2008. GMBI. (2008) Nr. 43/44, pp. 883-935; zul. geänd. GMBI. (2010) Nr. 43, p. 914.

[2] Wriedt, H., Das Risikoakzeptanzkonzept für krebserzeugende Gefahrstoffe, Gefahrstoffe - Reinhalt. Luft 70 (2010) Nr. 9, pp. 351-355

[3] Begründungen zu Exposition-Risiko-Beziehungen. www.baua.de/de /Themen-von-A-Z/Gefahrstoffe/TRGS/Begruendungen-910.html

[4] Gabriel, S.; Koppisch, D.; Range, D., The $M G U$ - a monitoring system for the collection and documentation of valid workplace exposure data, Gefahrstoffe - Reinhalt. Luft 70 (2010) Nr. 1/2, pp. 43-49.

[5] IFA-Arbeitsmappe Messung von Gefahrstoffen, ed. Deutsche Gesetzliche Unfallversicherung (DGUV), Berlin, Berlin: Erich Schmidt - Losebl.-Ausg. 1989.

[6] Stoffe mit Akzeptanz- und Toleranzkonzentration, ed. Institut für Arbeitsschutz der Deutschen Gesetzlichen Unfallversicherung (IFA), Sankt Augustin, www.dguv.de/ifa, webcode d120656.

[7] Technische Regel für Gefahrstoffe: Arbeitsplatzgrenzwerte (TRGS 900), Ausg. 10/2000, zul. geänd. BArbBl. (2004) Nr. 5; berichtigt BArbBl. (2004) Nr. 7/8.

[8] GESTIS-Gefahrstoffdatenbanken. ed. Institut für Arbeitsschutz der Deutschen Gesetzlichen Unfallversicherung (IFA), Sankt Augustin. www.dguv.de/ifa, webcode d3380.

[9] Technische Regeln für Gefahrstoffe: Teer und andere Pyrolyseprodukte aus organischem Material (TRGS 551), Ausg. 7/1999. BArbBl. (1999) Nr. 7-8, pp. 39-45, zul. geänd. BArbBl. (2003) Nr. 6, p. 90.

[10] Greim, H., Polycyclische Aromatische Kohlenwasserstoffe (PAH). Gesundheitsschädliche Arbeitsstoffe. Toxikologisch-arbeitsmedizinische Begründungen von MAK-Werten. 45. Lfg. ed. Deutsche Forschungsgemeinschaft, Weinheim: Wiley-VCH 2008 - Losebl.-Ausg.

[11] Steinhausen, $M$ et. al. Arbeitsbedingte Expositionen gegenüber krebserzeugenden, erbgutverändernden oder fortpflanzungsgefährdenden 
Substanzen in Deutschland, Gefahrstoffe - Reinhalt. Luft 72 (2012) Nr. 9, pp. 347-358

[12] Priority Pollutants, ed. United States Environmental Protection Agency (EPA), Washington D. C., USA. http://water.epa.gov/scitech/methods/cwa /pollutants.cfm

[13] Blome, H., Das ERB-Konzept - Was hat die Erprobung gebracht?, BGRCI.magazin, 9/10 2012, pp. 16-18. 